\title{
The Diversity of Rot Fungi from Cocoa Plantation and Its Ability to Grow on Carbon Source Media
}

\author{
DOI: 10.18196/pt.2019.102.125-129
}

\author{
Iradhatullah Rahim $^{1 *}$, Suherman ${ }^{1}$, Andi Nasaruddin ${ }^{2}$ \\ ${ }^{1}$ Department of Animal Husbandry and Fisheries, Faculty of Agriculture, Universitas Muhammadiyah Parepare, Parepare 91133, Indonesia \\ ${ }^{2}$ Department of Plant Pests and Diseases, Faculty of Agriculture, Hasanuddin University, Makassar, Indonesia \\ ${ }^{*}$ Corresponding author, email: iradhat76@gmail.com
}

\begin{abstract}
Rot fungiare microorganisms that can degrade biomass, especially biomass containing carbon. This fungus can decompose wood components (lignocelluloses) into simpler compounds. This research aimed to determine the diversity of rot fungi that have fruit body and grow in cocoa plantation as well as to observe their morphology and ability to grow on carbon source media. Fruiting body was taken from decayed cocoa stems from the farmers' cocoa plantation in Bila Village, Pitu Riase, Sidrap Regency, South Sulawesi. The fruiting body then was sterilized and grown on the PDA medium.. The isolates then were morphologically characterized and grown on a solid Czapek dox medium containing carbon source of lignin, chitin, cellulose, and pectin. The rot fungi from Basidiomycota found were Mycena spp, Lycoperdon spp, Auricularia spp, Schizophyllum spp, Coprinus spp, Tremella spp, Crepidopus spp, Trametes spp, and Pleurotus spp. The different growth abilities were characterized by the large diameter of the colony formed. The highest colony diameter of Lycoperdon spp was on cellulose media, while that of Tremella spp was on the three other media. The results show that the rot fungi from cocoa plant have a large potential to be used as biodecomposer.
\end{abstract}

Keywords: Biomass, Chitin,Lignin, Pectin, Tremella sp.

\section{ABSTRAK}

Cendawan pelapuk adalah mikroorganisme yang mempunyai kemampuan untuk mendegradasi biomassa, terutama biomassa yang mengandung karbon. Cendawan ini dapat menguraikan komponen kayu (lignosellulosa) menjadi senyawa yang lebih sederhana. Tujuan penelitian ini adalah untuk mengetahui keragaman cendawan pelapuk yang mempunyai tubuh buah dan tumbuh di pertanaman kakao. Selain itu untuk melihat karakterisasi morfologinya dan kemampuannya untuk tumbuh pada media sumber karbon. Tubuh buah cendawan pelapuk diambil dari batang kakao yang telah mati dari pertanaman kakao milik rakyat di Desa Bila, Kecamatan Pitu Riase, Kabupaten Sidrap, Sulawesi Selatan. Tubuh buah kemudian disterilkan dan ditumbuhkan pada media PDA secara aseptik dalam laminar air flow. Isolat kemudian dikarakterisasi secara morfologi. Isolat juga ditumbuhkan pada media Czapek dox padat yang ditambahkan sumber karbon berupa lignin, kitin, selulosa, dan pektin. Hasil penelitan menunjukkan cendawan pelapuk berasal dari Divisi Basidiomycota, yaitu Mycena spp, Lycoperdon spp, Auricularia spp, Schizophyllum spp, Coprinus spp, Tremella spp, Crepidopus spp, Trametes spp, dan Pleurotus spp. Cendawancendawan tersebut mempunyai kemampuan tumbuh yang berbeda-beda ditandai dengan besarnya diameter koloni yang terbentuk. Cendawan Lycoperdon spp mempunyai diameter koloni tertinggi pada media dengan selulosa sebagai sumber karbonnya. Sedangkan cendawan Tremella spp mempunyai kemampuan tumbuh tertinggi pada 3 media sumber karbon lainnya, yaitu Lignin, Kitin, dan Pektin. Hal ini menunjukkan bahwa cendawan pelapuk dari tanaman kakao berpotensi besar untuk dijadikan biodekomposer.

Kata Kunci: Biomassa, Kitin, Lignin, Pectin, Tremella sp.

\section{INTRODUCTION}

There are three groups of fungi in the nature that can decompose the components of wood (lignocellulose), namely brown rot, white rot, and soft rot. This grouping of rot fungi is based on the results of decomposing processes. Brown rot fungi produce brown residue, white rot fungi produce white residue, while the soft rot fungi produce residue which is like slimy. The three types of fungi have different characteristics. White rot fungi have the ability to degrade high lignin by causing a small loss of cellulose. The ability of white rot fungi to break down cell walls is better than other groups of organisms (Schmidt, 2006). The ability of the white rot fungi to degrade can be used to decompose the carbon contained in cocoa pod husk waste. Thus, it can be used as a source of plant nutrients.

White rot fungi are grouped based on microscopic characteristics of white pockets, white spots, and white filamentous. This is influenced by fungus species, wood species, and ecological conditions. In the decomposition process by white rot fungi, carbohydrates and lignin are degraded 
at the same time and at the same level during all stages of decomposition. The decay of the cell wall begins by producing micro hyphae holes on the secondary wall (Schmidt and Liese, 1966), which flow together for larger wall openings by expanding decay. Hyphae grow in the lumen close to the tertiary wall. Hyphae are covered by a layer of mucus that secretes active substances within only a direct distance of hyphae. Thus, the lysis zone of the hypha develops below, and the hypha produces grooves in the wall, which gradually decrease in thickness, such as rivers eroding the soil (Liese, 1970).

Many white rot fungi produce extracellular phenol oxidase, which is produced in positive oxidase tests on nutrients so that tannic and gallic acids are used. Only $40 \%$ of white rot fungi produce a combination of lignin peroxidase and manganese peroxidase, while a combination of manganese peroxidase and laccase is more common. Pycnoporus cinnabarinus, in extreme cases, only produces laccase, not lignin and manganese peroxidase $(\mathrm{Li}$, 2003 in Schmidt, 2006). This study aimed to determine the diversity of rot fungi isolated from cocoa plantations as well as to observe the ability of the rot fungi to grow on carbon source media, which is one indicator of the fungus ability decompose organic materials.

\section{MATERIALS AND METHODS}

Isolation and Screening of Rot Fungi Isolates

The fruiting body of the fungi growing on the decomposed cocoa plants was taken using tweezers and put into a paper envelope. The body of the fruit was brought to the laboratory then cut into pieces with a size of $1 \times 1 \mathrm{~cm}$. The fruit body was rinsed with sterile water then dipped in 70\% alcohol for 2 seconds. The fruit body then was rinsed again with sterile water and then isolated on PDA media for screening. Screening was done by purifying and separating fungi based on their morphological characteristics.
The Growth of Rot Fungi Isolates on Carbon Source Media

This testing used solid Czapek dox media. The media were added with 0.1\% Remazol Brillant Blue and divided into 4 parts. Each part was added with carbon source substrate, namely Carboxy Metil Cellulose (CMC) as source of cellulose, Lignin quaicol benomyl as source of lignin, crab shell as source of chitin, and sawdust as source of pectin. The media were homogenized on the hot plate stirrer for 15 minutes, then sterilized in autoclave for 2 hours. After cold, the media were poured on a sterile petri dish in Laminar Air Flow. Fungi isolates were cut using a cork borer, grown on the media, and incubated in a dark place for 7 days. There were 60 combinations of treatments (6 types of media and 10 types of isolates), each treatment combination consisted of 2 replications, resulting in 120 units of observation. Based on the method from Wirth \& Wolf (1990), two to three days after cultivation, a bright colored zone around the culture will be formed. Growing ability was obtained by measuring the diameter of the colony 7 days after incubation.

\section{RESULTS AND DISCUSSION}

Isolation and characterization of Rot fungi from cocoa plantations

There were 10 isolates of rot fungi successfully isolated from cocoa plantations. Morphological characterization is shown in Table 1 . Table 1 clearly shows that there were 10 types of isolates obtained from cocoa plantations. Each isolate was pure white to orange with a smooth to rough texture. The rot fungi found were included in the Basidiomycota. Basidiomycota have a large fruit body so they are easy to observe. The fruit body consists of a hood (pileus), blades (lamella), and stalk or stipe (Webster \& Weber, 2007).

Colonies of rot fungi isolates varied, although all isolates were grown on the same medium, which was the potato dextrose agar (PDA) medium. The 
Table 1. Morphological characterization of rot fungi isolates isolated from cocoa plantations

\begin{tabular}{|c|c|c|c|c|c|}
\hline \multirow{2}{*}{ Rot Fungi } & \multicolumn{5}{|c|}{ Morphological characterization } \\
\hline & Colony color up & Colony color down & Shape & Texture & Exudate drops \\
\hline Mycena sp & Lily-white & White & rounded compact & smooth & have \\
\hline Lycoperdon sp & Yellowish white & White & edging serrated & slightly rough & not \\
\hline Auricularia sp & smooth orange & yellowish & ring shape & smooth & not \\
\hline Schizophyllum sp & yellow & yellowish & ring shape & smooth & have \\
\hline Coprinus sp & white & white & rounded edges & smooth & not \\
\hline Tremella sp & grey white & greyish & filamentous & slightly rough & not \\
\hline Crepidotus sp & lily-white & white & dense edge & smooth & have \\
\hline Tremetes sp & yellowish white & pale yellow & rounded & smooth & not \\
\hline Pleurotus sp & white & white & filamentous & smooth & not \\
\hline
\end{tabular}

variety of color, shape, and texture of the rot fungi presence of lignocellulosic enzymes produced by colonies obtained in this study were closely related fungi to grow and degrade the carbon sources in the to genetic factors. According to Baon, Wedhastri, media. Enzyme is one of the secondary metabolites \& Kurniawan (2012), besides being influenced by produced by fungi. Garraway and Evans (1984) genetics, variations in colonies may be caused by state that the secondary metabolite production environmental conditions in the sample area and phase occurs due to unfavorable environmental growth media, including carbon sources, tempera- conditions. Some reports showed that the growth ture, and $\mathrm{pH}$. Although the fungi were taken from the same cocoa plantation, the weather conditions and decayed wood media where the fungi grow were different. Color differences in colony can be influenced by temperature during the laboratory tests and the availability of nutrients in the medium (Ambar et al., 2010; Rozlianah \& Sariah, 2006).

\section{Growing Ability on Carbon Source Media}

All rot fungi isolates obtained from cocoa plantations showed the ability to grow on carbon source media. This was indicated by the formation of a bright zone (Figure 1). The bright zone showed the

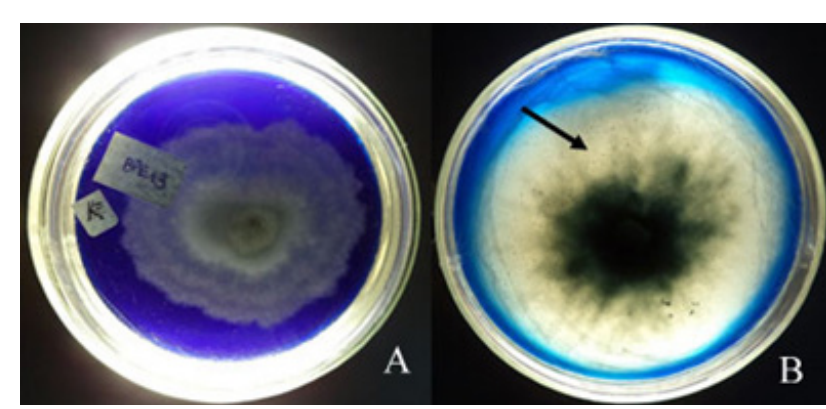

Figure 1. Bright zones (arrows) indicating the ability of fungi to grow on carbon source media (B) compared to without carbon sources as control (A). of fungi on a solid substrate was different when grown in liquid media because of the presence of surface phenomena, moisture, and chemical composition of the substrate. This will affect the production of lignin peroxide ( $\mathrm{LiP}$ ) which is also a secondary metabolite (Hatakka, 1983).

The rot fungi isolates were grown on solid Czapek dox media added with carbon sources, namely lignin, chitin, cellulose, and pectin. The types of isolates and types of carbon source media had a very significant effect on the diameter of the rot fungi colonies. However, the interaction effect between the two treatments was not significant. There were no significant differences between the fungi grown on the media, but the diameter of the colony isolates of the fungi was the highest in Tremella sp, which was $6.96 \mathrm{~cm}$ (Table 2). Tremella sp has an orange, thin, and chewy fruiting body. This fungus is in the Agaricomycotina subdivision, Tremellomycetes, class and Tremellales order (Chen, 1998). The fruiting body is yellow, orange, or brownish. Intensity variations of fruiting body color can be caused by variations in carotenoids 
Table 2. Colony diameter (cm) of various rot fungi isolates from cocoa plantations on carbon source media at 7 days after incubation

\begin{tabular}{lcccc}
\hline \multirow{2}{*}{ Rot Fungi } & \multicolumn{4}{c}{ Diameter $(\mathrm{cm})$ of colonies in carbon source media } \\
\cline { 2 - 5 } & Lignin & Chitin & Cellulose & Pectin \\
\hline Mycena sp & 6.08 & 5.03 & 4.83 & 4.00 \\
Lycoperdon sp & 6.12 & 6.78 & 7.22 & 3.13 \\
Auricularia sp & 3.47 & 2.95 & 2.20 & 3.67 \\
Schizophyllum sp & 4.23 & 4.30 & 4.20 & 3.73 \\
Coprinus sp & 3.83 & 4.48 & 5.27 & 2.93 \\
Tremella sp & 6.98 & 7.35 & 6.27 & 7.23 \\
Crepidotus sp & 3.83 & 5.60 & 5.18 & 3.00 \\
Tremetes sp & 2.72 & 1.10 & 1.10 & 1.10 \\
Pleurotus sp & 4.10 & 6.06 & 7.00 & 4.27 \\
\hline Average & $4.61 \mathrm{ab}$ & $5.01 \mathrm{a}$ & $5.02 \mathrm{a}$ & $3.78 \mathrm{~b}$ \\
\hline
\end{tabular}

Remarks: Means followed by the same letters were not significantly different according to DMRT at the level of $\alpha=0.01$.

by light intensity (Wong, Fares, Zimmermann, Butler, \& Wolfe, 2003). Tramella sp also had the highest colony diameter on the Potato Dextrose Agar (PDA) media and filled up the petridish on the third day (data not shown).

Table 2 clearly shows that Tremella sp fungi has the higher colony diameter on lignin, chitin, and pectin media than other isolates. This was related to the ability of Tremella sp to produce high phytohormones than others. The concentration of IAA and GA3 produced by Tremella sp was $2.44 \mu \mathrm{gL}-1$ and $4.11 \mu \mathrm{gL}-1$, respectively, while the IAA and GA3 produced by Pleurotus sp fungi were $2.44 \mu \mathrm{gL}-1$ and $4.11 \mu \mathrm{gL}-1$, consecutively (Rahim, Nasruddin, Kuswinanti, Asrul, \& Rasyid, 2018). The ability to produce phytohormones is related to the ability to grow in carbon source media. This causes Tremella sp to have the potential to become a biodecomposer for organic media from agricultural waste, which is mostly composed of carbon compounds.

The growth of rot fungi isolates on pectin media was not significantly different from the growth on lignin media. However, it was significantly different from the growth on chitin and cellulose media. The four media used to grow isolates of rot fungi were the carbon sources. This showed the ability of fungi to grow on these media. Carbon sources were degraded to be used as energy and structural sources of fungal cells (Chang and Miles, 1989). Carbon compounds that can be used by fungi include monosaccharides, oligosaccharides, organic acids, alcohol, cellulose, and lignin. The most easily absorbed carbon source is glucose (Hendritomo, 2002).

The best growth of rot fungi was observed on media containing cellulose. This was indicated by the highest diameter of the colony, which was 5.02 $\mathrm{cm}$, although it was not significantly different from that on chitin media, which was $5.01 \mathrm{~cm}$ (Table 2). High cellulose content will increase cellulase enzyme production, and this has an important relationship with the formation of the fruiting body (Sivaprakasam et al., 1994; Sulistyarini, 2003). Meanwhile, chitin is the second largest polymer after cellulose which functions to regulate the growth and development of fungi by controlling lysis and synthesis of cell walls and skeletons (Hamid R et al., 2013; Ayes et al., 1994), therefor, the addition of chitin to the media has various influences on the existed organisms (Sharp, 2013). 


\section{CONCLUSION}

There were 10 isolates of rot fungi isolated from cacao plantation, namely Mycena spp, Lycoperdon spp, Auricularia spp, Schizophyllum spp, Coprinus spp, Tremella spp, Crepidopus spp, Trametes spp, and Pleurotus spp. The fungi have different growth abilities indicated by the diameter of the colonies formed. Lycoperdon spp has the highest colony diameter in the media with cellulose as its carbon source. Meanwhile, Tremella spp has the highest growth ability in the three other carbon source media, namely lignin, chitin, and pectin.

\section{REFFERENCES}

Ambar, AA., (2010). Tanggapan Tomat Varietas Tahan dan Rentan terhadap Asam Fusarat dan Fusarium oxysporum f.sp.Lycopersici. Disertasi tidak diterbitkan. Program Pascasarjana, Fakultas Pertanian, UGM. Yogyakarta.

Ayes, M.D.; Howard, S.C.; Kuzio, J.; Lopez-Ferber, M.; Possee, R.D. (1994). The complete DNA sequence of Autographa californica nuclear polyhedrosis virus. J.Virology (202) page 586-605.

Baon, J. B., Wedhastri, S., \& Kurniawan, A. (2012). The Ability of Phosphate Solubilizing Bacteria Isolated from Coffee Plant Rhizosphere and Their Effects on Robusta Coffee Seedlings, 2, 1064-1070.

Chang, S.T, Miles, P.G. (1989). Edible mushrooms and their cultivation. Florida: CRC Press, Inc. 451.

Chen C.J, (1998). Morphological and molecular studies in the genus Tremella. Berlin: J. Cramer:. 225.

Garraway, M.O, Evans, R. (1984). Fungal Nutrition and Physiology. John Wiley and Sons, Paris.

Hamid, R.; Khan, M.A.; Ahmad, M.; Ahmad, M.M.; Abdin, M.Z.; Musarrat, J.; Javed, S, (2013). Chitinases: An update. J. Pharm. BioAllied Sci.(5):21-29.

Hatakka, A. (1983). o = ; Applied Microbiology and Biotechnology Pretreatment of Wheat Straw by White-Rot Fungi for Enzymic Saccharification of Cellulose, 350-357.

Hendritomo HI., (2002). Biologi Jamur Pangan. Pusat Pengkajian dan Penerapan Teknologi Bio Industri. Jakarta.

Liese W (1970) Ultrastructural aspect of Woody tissue distintegration. Ann Rev Phytopath 8:231-258.

Rahim, I., Nasruddin, A., Kuswinanti, T., Asrul, L., \& Rasyid, B. (2018). Utilization of Cocoa Pod Husk Waste Composting by Tremella Sp and Pleurotus Sp as A Medium to Growth of Cocoa Seedling. IOP Conference Series: Earth and Environmental Science, 156(1). https://doi.org/10.1088/1755-1315/156/1/012012

Rozlianah, F. ., \& Sariah, M. (2006). Characterization of Malaysian Isolates of Fusarium from Tomato and Pathogenicity Testing. pdf. Research Journal of Microbiology, 1(3), 266-272.
Schmid R, \& Liese, W (1966) Elektronen mikroskopische Beobachtungen an Hyphen von Holzpilzen. Sippl 1 Mater Org, pp. 251-261.

Schmidt, 0. (2006). Wood and Tree Fungi; Biology, Damage, Protection, and Use. (D. C. Heidelberg, Ed.). Berlin, Germany.

Sharp, R. G. (2013). A Review of the Applications of Chitin and Its Derivatives in Agriculture to Modify Plant-Microbial Interactions and Improve Crop Yields, 757-793. https://doi.org/10.3390/ agronomy3040757

Sulistyarini, S. (2003). Produksi jamur tiram putih (Pleurotus florida) pada media campuran serbuk gergaji dan sekam padi. Universitas Diponegoro. Retrieved from http://eprints.undip. ac.id/29642/

Webster, J., \& Weber, R. (2007). Introduction to Fungi (Third). Camridge University Press.

Wirth, S. J., \& Wolf, G. A. (1990). Dye-labelled substrates for the assay and detection of chitinase and lysozyme activity, 12, 197-205.

Wong, S., Fares, M. A., Zimmermann, W., Butler, G., \& Wolfe, K. H. (2003). Evidence from comparative genomics for a complete sexual cycle in the 'asexual' pathogenic yeast Candida glabrata. Genome Biology, 4(2), 1-9. 